\title{
DOSEN DAN PERTUMBUHAN ILMU PENGETAHUAN
}

\author{
Dominikus Tulasi \\ Marketing Communication Department, Faculty of Economic and Communication, BINUS University \\ Jln. K.H. Syahdan No. 9, Palmerah, Jakarta Barat 11480 \\ dtulasi@binus.edu
}

\begin{abstract}
The primary purpose of this research is to know lecturers' activities as the agent of science growth through scientific research and how they highlight a phenomenon using deductive apriory perspective and inductive aposteriory perspective. Deductive apriory perspective is a way to prove an empirical data referring to general propositions that is certain relevant theories with a unit analysis and research object. Whereas, inductive aposteriory perspective is the way oppose to deductive apriory, namely, proving in advance the empirical data on the spot, then followed by creating concepts and propositions which estuary on forming and formulating theory. In other words, deductive and inductive perspective is the binary opposition. Doing research using deductive way is the positivistic aprovident with quantitative approach generating singular truth. Doing research inductively refers to post-positivistic aprovident with qualitative approach affecting on multifaced truth. Research method used in this study is the inductive-explorative-qualitative approach, a case study using communication semiotics analysis, estuary at researcher's internalization toward the phenomenon of lecturers' scientific activities of Economics and Communication Faculty at Binus University. Result obtained of this study is to reconstruct researcher's comprehension of lecturers' scientific research accumulated in appropriate concepts and propositions using deductive-quantitative and inductive-qualitative approach in its implementation on scientific research of Economics and Communication Faculty lecturers at Binus University. Based on the result it can be concluded that applying scientific research activities of lecturers' holistic understanding toward deductive apriory and inductive apsoteriory will generate satisfied result of a research. Improving and intensifying a phenomenon by implementing quantitative and qualitative methods rightfully, following scientific rules, will affect scientific values as expected. Whereas, in some cases, lecturers apply mixed method using quantitative and qualitative approach simultaneously in studying a phenomenon.
\end{abstract}

Keywords: deductive apriory, quantitative, inductive aposteriory, qualitative, binary opposition

\section{ABSTRAK}

Tujuan penelitian adalah untuk mengetahui aktivitas dosen sebagai agen pertumbuhan ilmu pengetahuan melalui kegiatan ilmiah dan bagaimana dosen melihat suatu fenomena melalui perspektif deduktif apriori atau perspektif induktif aposteriori. Perspektif deduksi apriori adalah cara pandang bahwa proses pembuktian data empiris mengacu pada proposisi umum berupa teori tertentu, yang dianggap relevan dengan unit analisis dan objek penelitian. Sebaliknya, perspektif induktif aposteriori adalah cara pandang yang beroposisi terhadap deduksi apriori, yakni harus ada pembuktian terlebih dahulu pada fakta di dunia nyata, dan diikuti dengan penciptaan konsep dan proposisi yang bermuara pada bentukan dan formulasi teori. Dalam tradisi berpikir ilmiah sesungguhnya terdapat pemisahan jelas antara keduanya. Dengan kata lain, perspektif deduktif dan induktif adalah oposisi keduaan (binary opposition). Kelak kemudian, meneliti secara deduktif mengikuti cara pandang paham positivistik dengan metode kuantitatif yang hasilnya melihat kebenaran bersifat tunggal. Meneliti secara induktif bertolak dengang cara pandang paham post-positivistik dengan metode kualitatif yang melihat kebenaran fakta secara jamak. Metode yang digunakan dalam penelitian ini adalah induktif-eksploratif-kualitatif, dengan metode studi kasus menggunakan daya analisis semiotika komunikasi, yang bermuara pada internalisasi peneliti terhadap fenomena aktivitas dosen Fakultas Eknomi dan Komunikasi Binus University. Hasil penelitian yang diperoleh dari penelitian ini adalah merekonstruksi pemahaman peneliti tentang aktivitas ilmiah dosen berupa konsep dan proposisi yang bersesuaian dengan cara pandang deduktif-kuantitatif dan induktif-kualitatif dalam implementasinya pada penelitian ilmiah dosen Fakultas Ekonomi dan Komunikasi Binus University. Simpulan yang diperoleh dari penelitian ini yaitu penerapan aktivitas penelitian ilmiah dosen dengan pemahaman yang komprehensif terhadap cara pandang deduktif apriori maupun cara pandang induktif aposteriori akan memberikan hasil yang memuaskan. Membuktikan ataupun mendalami suatu fenomena dengan menerapkan metode kuantitatif maupun kualitatif dengan benar, mengikuti kaidah ilmiah, akan melahirkan nilai-nilai ilmiah sesuai harapan. Sebaliknya pada kasus tertentu, para dosen menerapkan metode campuran yakni menggunakan metode kuantitatif dan kualitatif sekaligus dalam membedah suatu fenomena.

Kata kunci: deduktif apriori, kuantitatif, induktif aposteriori, kualitatif, binary opposition 


\section{PENDAHULUAN}

Dalam memelihara pertumbuhan ilmu, seorang dosen dituntut untuk menghayati dua pilar ilmu pengetahuan sekaligus. Pertama, pemahaman yang mendalam dan komprehensif tentang pendekatan deduktif positivistik. Kedua, pemahaman lengkap dan holistik mengenai pendekatan induktif post-positivistik. Metode pendekatan deduksi apriori yang idealis berkiblat positivistik dalam arti memandang kebenaran bersifat tunggal (quantitative approach). Sebaliknya, pendekatan induktif aposteriori memandang kebenaran bersifat "jamak" (multifaced). Keseimbangan dalam menghayati dan memberi makna pada pendekatan deduktif dan induktif bagi seorang dosen, adalah suatu keniscayaan. Keutuhan memahami dan menerapkan kedua pendekatan dalam membaca suatu fenomena akan memberi makna (meaning) yang lengkap. Itulah sebabnya, seorang dosen dituntut memahami kedua pilar ilmu ini, sebagai substansi dan esensi pertumbuhan ilmu pengetahuan sekaligus, meski dalam aplikasinya harus memilih salah satu di antara kedua metode ini dalam membaca suatu fenomena.

Penelitian ini mencoba menyoroti karya-karya ilmiah para dosen Fakultas ekonomi dan komunikasi Binus University sebagai unit analisisnya, terutama penelitian ilmiah yang umumnya digunakan oleh para dosen selama lima tahun terakhir. Terdapat kesenjangan yang cukup terjal bagi para dosen menggunakan kedua pilar ilmu tersebut dalam pengembangannya. Bagi dosen-dosen jurusan Manajemen dan akuntansi hampir seluruhnya menggunakan pendekatan deduktif-kuantitatif. Sementara itu jurusan Marketing Communication umumnya menggunakan pendekatan induktifkualitatif. Hal ini dapat dipahami, oleh karena jurusan yang disebutkan terakhir berkiblat pada komisi ilmu-ilmu sosial. Di antara kedua pilar ilmu tersebut di atas, terdapat konstruksi penyambung sebagai sintesis-nya yang disebut subduksi. Subduksi adalah tinjauan filosofis yang men-sintesis-kan kedua pilar tersebut.

\section{Paradigma Penelitian}

Tuntutan penguasaan paradigma penelitian tingkat lanjut, selalu mendahulukan dua pandangan di atas sebagai dasar berlogika. Dan, pada tingkat pendidikan doktoral biasanya kedua pilar ilmu ini dipelajari intensif untuk menyelesaikan disertasi. Mahasiswa strata tiga rumpun ilmu-ilmu sosial termasuk ilmu ekonomi yang pemahamannya kurang lengkap untuk kedua pilar ini, umumnya akan lama lulus dari pendidikan doktornya. Oleh karena, aliran-aliran besar dalam filsafat ilmu pengetahuan bertolak dari kedua pilar ilmu ini. Dan di sekitar dua pilar ilmu ini, muncul berbagai aliran di sekitarnya guna mempertajam analisis masalah dan fenomena sosial.

Dalam konten metodologi penelitian, kita berada dalam dua paradigma besar pertama, filsafat aliran positivisme dan rumpun pemikiran di sekitar positivisme seperti: empirisme, behaviorisme, naturalisme serta sainsisme. Kedua, aliran post-positivisme yang dikembangkan dari ajaran Plato tentang dunia idea dan humanisme serta rasionalitas manusia. Gagasan Plato memengaruhi Edmun Husserl, Martin Heidegger, dan Merleau Ponty, yang kesemuanya adalah pelopor aliran fenomenologi. Aliran ini menekankan bahwa terdapat sintesis antara kesadaran rasio manusia dengan fenomena kehidupan, yang selalu berhubungan secara dialektis. Dalam pandangan fenomenologi sesuatu tampak pasti bermakna menurut subjek yang menampakkan fenomena tersebut. Oleh karena setiap fenomena berasal dari kesadaran manusia sehingga niscaya mengandung makna. Maka, kita menjadi ragu bahwa dosen-dosen yang membimbing skripsi atau tesis mahasiswa, hanya memahami salah satu metode di antara kedua pilar ilmu ini, akan membimbing dengan benar. Sebab, belumlah lengkap seorang dosen pembimbing hanya memahami salah satu pendekatan saja.

Terdapat perbedaan signifikan antara berpikir deduktif aliran positivistik yang diwujudkan dalam metode kuantitatif, dan berpikir induktif post-positivistik yang diwujudkan dalam metode kualitatif. Meneliti dengan pendekatan deduktif kuantitatif seperti yang nampak pada hasil penelitian 
dosen-dosen jurusan manajemen dan akuntansi, yang menjadi substansi dan esensi penelitian bertumpu pada teori yang dikonstruksi sedemikian, untuk dibuktikan kebenarannya dilapangan.Terdapat jarak antara subjek peneliti dan objek yang diteliti serta bebas nilai, oleh karena dilaksanakan melalui survei instrumen pertanyaan, dan kemudian diuji kebenarannya secara statistik. Dalam kaitan ini penulis memberi makna baru bahwa penelitian survei, validitasnya terakumulasi dan muatan hasilnya dipikirkan oleh responden. Sebaliknya, meneliti dengan pendekatan kualitatif induktif, substansi dan kerangka berpikirnya tidak seluruhnya bertumpu pada teori. Sebab, ketika memasuki wilayah penelitian, seorang peneliti bukan berpikir untuk membuktikan teori, melainkan berpikir bagaimana menjadikan teori itu sebagai lampu sorot (spot light) untuk melihat masalah dan mencatatnya dari sumber pertama dan sumber derivatifnya.

Substansi penelitian kualitatif hakekatnya bersumber dari diri peneliti sendiri. Esensi penelitian yang terkait dengan substansi sesungguhnya melekat pada kehendak subjek peneliti. Itu sebabnya, mempertanyakan validitas hasil penelitian, sesungguhnya bersemayam dalam logika dan konstruksi berpikir seorang peneliti. Sebagai peneliti, seorang dosen tidak pernah akan berangkat dari titik "zero" dalam merekonstruksi masalah dilapangan. Namun, diharapkan bahwa peneliti akan mencatat dan merunut masalah secara metodis serta memproduksinya dengan baik melalui bahasa yang sistematis pula. Peneliti Clifford Geertz misalnya pernah berkata, "dalam meneliti, kita tidak hanya mencatat, akan tetapi kita juga dicatat.” Dengan kata lain, meneliti secara kualitatif, tumpuan dan maknanya bersumber dari diri seorang peneliti. Dia harus mampu mendekonstruksi masalah, dan mampu pula merekonstruksi masalah melalui kemampuan berpikirnya; sebab, meneliti adalah berpikir. Terkait dengan penelitian kualitatif-induktif, dalam pembahasan, peneliti menghadirkan analisis semiotika guna mempertajam kedalaman makna pada pembahasan tulisan ini. Pertanyaan sebagai fokus penelitian adalah tentang hakikat penelitian para dosen terinspirasi dari dua pilar ilmu pengetahuan. Dalam kaitan strukturalisme dan semiotika, terdapat beberapa masalah yang muncul ditemukan dan patut dipertanyakan; (1) konsep-konsep dan proposisi-proposisi yang hendak didekonstruksi dan direkonstruksi sebagai sistem konstitusi semiotika komunikasi, dan (2) metode semiotika komunikasi yang mampu mendekonstruksi tanda pada setiap fenomena yang ditemukan dalam penelitian kualitatif-induktif post-strukturalisme.

\section{Post-strukturalisme}

Post-strukturalisme adalah aliran filsafat ilmu dan label yang dirumuskan oleh beberapa akademisi Amerika sekitar tahun 60-an hingga 70an, sebagai sebuah respons dan reaksi kritis terhadap aliran filsafat struktural yang berkembang pesat di Perancis tahun 50-an hingga 60an. Aliran strukturalisme merupakan sebuah gerakan intelektual yang dikembangkan dan berkembang di kawasan Eropa sejak awal abad 20 hingga pertengahan abad 20. Gerakan ini mempelajari struktur sebagai sebuah produk budaya tekstual melalui pemaknaan bahasa yang tak dapat digugat, oleh karena segala sesuatu terjadi dan hadir sebagai wujud dari konvensi kelompok masyarakat itu sendiri. Konsep-konsep analitis dari bahasa, psikologi, antropologi dan bidang-bidang lain diinterpretasi ke dalam struktur ke-dua-an (binary opposition).

Fokus utamanya adalah logika dan sifat ilmiah sebagai hasilnya. Aliran ini beranggapan dan mengkonstruksi semua tanda termasuk kebudayaan bahwa segala sesuatu dipahami dan dimaknai sebagai sebuah kesepakatan melalui bahasa sebagai alatnya. Segala sesuatu merupakan realitas terkonstruksi dalam bahasa yang bersifat mendua (binary). Aliran ini lebih fokus pada paham bahasa yang bersifat sinkronik dimana waktu seakan dimatikan (slash of time). Manusia dikonstruksi alam sadarnya untuk memahami wujud "masculinum” oleh karena berhadapan dengan "femininum”. Dalam pemaknaan, seorang suami yang penuh kasih sayang memberikan sekuntum "bunga mawar" kepada kekasih atau istri pada hari ulang tahunnya, dan di balik objek bunga mawar itu, secara metafisik merupakan tanda "cinta” (love). Makna cinta yang terkandung dibalik objek bunga mawar, merupakan makna konvensi yang terus diwariskan. Dengan kata lain, paham strukturalisme bersifat baku dan konstan. Dan, dalam hubungan dengan penelitian ini pendekatan deduktif-induktif adalah opsisi ke- 
dua-an (binary opposition). Sementara aliran-aliran di sekitarnya merupakan hyper realitas yang dinamis dan bersifat ilmiah.

Hingga saat ini makna yang disepakati terkonstruksi kokoh demikian.Tokoh-tokoh aliran strukturalisme adalah Ferdinand de Saussure, Roland Barthes, Charles Sanders Pierce, sedangkan tokoh-tokoh post-strukturalisme adalah Jacques Derida, Michel Foucault, Gilles Deleuze, Judith Butler, Jacques Lacan, dan Julia Kristeva. Kelompok aliran ini mengkritik tajam dan mempertanyakan premis-premis mapan struktur, menawarkan sebuah "cara" dan mempertanyakan bagaimana pengetahuan dapat diproduksi. Oleh karena menciptakan ilmu pengetahuan tidak dengan cara dekonstruksi-rekonstruksi, melainkan dengan cara memproduksi. Pertanyaannya adalah, apakah dosen-dosen jurusan manajemen dan akuntansi serta marketing communication melakukan penelitian untuk merekonstruksi atau memproduksi karya ilmiah? Dalam observasi dan analisis, peneliti menemukan banyak hal yang nampak baru, namun, konstruksi penalaran argumentatif tetaplah hasil rekonstruksi dan reproduksi dari realitas yang telah ada atau yang diadakan sebelumnya.

\section{Post-positivisme dan Semiotika}

Para peneliti beraliran positivistik kuantitatif seperti dosen-dosen jurusan manajemen dan akuntansi, kebanyakan masih memandang bahwa, penelitian kualitatif induktif kurang ilmiah, oleh karena mereka melihat dataran permukaan penelitian induktif kualitatif, hanya mencatat. Namun, apabila ditelisik lebih dalam, peneliti kualitatif dengan depth interview sesungguhnya memiliki nilai ilmiah yang esensial, mampu mendekonstruksi masalah, dan memaknainya tidak hanya secara denotatif, melainkan jauh lebih dalam memberi makna konotatifnya. Istilah denotatif dan konotatif sendiri adalah konstruksi ke-dua-an (oposisi biner). Dalam semiotika, dua sudut pandang yang dipopulerkan oleh Ferdinand de Saussure dan Roland Barthes penerusnya, melihat segala sesuatu yang telah terkonstruksi sebagai "penanda" (signifier) dan "petanda" (signified) yang utuh berwujud "tanda" dalam ilmu pertandaan. Penanda adalah bentuk permukaan yang menjadi "jangkar" sesuatu untuk memberi kemungkinan ditafsir dan dipersepsi lebih lanjut mendalam sebagai petandanya. Dengan demikian, penanda dan petanda adalah struktur dan sistem tanda (sign) itu sendiri.

Ruang penanda (signifier) dalam hasil penelitian para dosen, baik jurusan manajemen dan akuntansi maupun marketing communication adalah pesan informatif yang sangat tergantung kepada persepsi dan latarbelakang yang melingkupinya. Semua data dan analisis nya termasuk dalam kategori penanda. Sebaliknya, interpretasi lebih jauh tentang data dan validitas serta reliabilitas-nya adalah petanda yang diperlihatkan untuk memberi keyakinan pada pembacanya. Bertolak dari semiotika Roland Barthes, terbuka kemungkinan setiap peneliti dapat merangkai dan merunut sendiri definisi untuk mempersepsi penanda (signifier) dan petanda (signified) guna menemukan inti relasi di antara ke duanya yang mewujudkan 'tanda' (sign) sebagai sebuah totalitas sistem signifikasi. Penggunaan tanda secara sosial dalam berbagai media komunikasi juga termasuk dalam pengertian ini: misalnya, penelitian deduktif, induktif, fenomenologi, teori kritis bahkan iklan, komik, film, dan seterusnya.

Semua sistem tanda itu akan dapat menjadi rujukan berharga dalam berbagai upaya pengembangan lebih mendalam. Secara induktif aliran post-positivistik yang berhubungan erat dengan hyper-realitas, ditemukan kenyataan yang bersifat hybrid, akan tetapi secara umum konstruksi penelitian masih tetap statis mengikuti format yang baku sesuai ketentuan institusi Binus University. Hampir tidak ditemukan bangunan pemikiran yang berkembang di luar bangunan logika baku. Esensi bangunan penelitian deduktif apriori yang dikembangkan dari latarbelakang bertumpu pada perumusan masalah dan bermuara pada hipotesis, merupakan bangunan logika klasik. Sementara hasil penelitian survei yang dianalisis pada bab empat semua penelitian adalah bentuk lama yang selalu berulang direproduksi. Semua laporan penelitian merupakan hasil rekonstruksi yang didaur ulang oleh setiap peneliti. Pada titik itu peneliti memastikan bahwa, hampir tak ditemukan makna baru yang bersifat dekonstruktif. Makna atau konsep yang "terbaring” di dalam format penelitian nampak sebagai penanda (signifier) yang menjadi “jangkar” untuk diinterpretasi lebih dalam. Namun, makna-makna 
dari konsep maupun proposisi-proposisi yang abstrak itu, tetap stagnan dan konstan mengikuti konstruksi lama seperti yang kita saksikan pada paham strukturalisme. Selalu dalam proses menjadi, dalam konstelasi permainan penanda yang tanpa akhir. Bidang penanda dan petanda dianggap terstruktur tak terpisahkan, menyatu seperti selembar kertas sebagaimana dikatakan Saussure (Piliang, 2010). Secara ontologis terpapar dan terbaring memenuhi persyaratan ilmiah. Namun, secara epistemologis berjalan "normal” tidak mengalami dinamika yang serius. Hukum dialektika tidak begitu nampak dalam dinamika analisis yang dikembangkan.

Secara teoritis semua uraian di atas tercakup di dalam semiotika signifikasi, semiotika komunikasi, dan semiotika ekstra-komunikasi. Kajian terhadap ketiga lingkup di atas saling tergantung dan saling terkait bersistem. Secara semiotika semua hal yang dialami manusia dapat dikelompokkan dalam tanda yang berwujud: penanda-petanda menurut Ferdinand de Saussure yang bergulat dengan linguistik, dan Charles S. Peirce menamainya: ikon, index, dan simbol. Jika dirunut lebih jauh maka, baik Saussure maupun Peirce telah menciptakan 'alat' yang memperlihatkan bahwa kedua pemikiran dapat menghadirkan pesan verbal, non verbal bahkan pesan visual yang lebih memudahkan manusia dalam melakukan komunikasi.

\section{DISKUSI DAN PEMBAHASAN}

Secara etimologis, istilah semiotika berasal dari kata Yunani semeion "tanda” (sign). Jadi, semiotika didefinisikan sebagai ilmu tanda dan studi sistem, aturan-aturan dan konvensi-konvensi yang memungkinkan tanda memiliki makna. Atau, dalam Yunus \& Tulasi, (2012) dikatakan "semiotics can be defined as the science of signs and the study of the systems, rules and conventions that allow these sign to have meaning." Tanda juga didefinisikan sebagai sesuatu dan atas dasar konvensi sosial yang dibangun sebelumnya dianggap mewakili sesuatu yang lain. Secara terminologis, semiotika didefinisikan sebagai ilmu yang mempelajari sederetan objek-objek, peristiwa-peristiwa, dan seluruh kebudayaan sebagai tanda (Sobur, 2006).

Penelusuran dokumentasi yang dilakukan umumnya menyebutkan bahwa cikal bakal ilmu semiotika bermula dari ilmu linguistik dengan tokoh utamanya Ferdinand de Saussure (1857-1913). Meski Saussure lebih populer sebagai Bapak Linguistik, namun idenya di bidang semiotika juga dirujuk oleh ilmuwan semiotik sesudahnya melalui buku fenomenalnya "Course in general linguistics” (1916). Di dalam buku ini Saussure membayangkan suatu ilmu yang mempelajari tentang tanda-tanda yang digunakan dalam realitas sosial masyarakat manusia. Semiotika/semiologi penelitian didasarkan pada asumsi bahwa selama perbuatan atau tingkah laku meneliti membawa makna atau selama berfungsi sebagai tanda, dibaliknya sistem pembedaan dan konvensi memungkinkan makna itu ada. Di mana ada tanda, di sana ada sistem (Saussure).

Dalam hubungan penelitian induktif ini, peneliti berkeyakinan bahwa hasil-hasil penelitian yang ada, apakah yang bersifat apriori ataupun yang bersifat aposteriori merupakan bentangan ontologis yang senantiasa didaur ulang, dan akan terus didaur ulang. Bagi penulis, bentangan semua konsep maupun proposisi-proposisi yang terkandung di dalamnya adalah penanda (signifier). Dan kandungan makna yang ditafsirkan peneliti yang bersifat subjektif adalah petanda (signified) baru. Dalam paradigma Saussure, bahasa terdiri dari sejumlah tanda yang terdapat dalam jaringan sistem dan disusun dalam struktur-struktur tertentu. Saussure mencontohkan kata arbor (Latin) yang artinya pohon. Kata ini terdiri dari arbor (pohon) dan "konsep" tentang arbor (pohon). Significant (arbor) disebut citra akustik yang memiliki relasi dengan konsep pohon (bukan pohon tertentu) yakni signifier/signified.

Dalam penelitian deduktif positivistik maupun penelitian induktif post-positivistik, format bakunya bersama semua konsep atau proposisi-proposisi yang ada didalamnya adalah seperti "arbor" 
objeknya dan makna terinterpretasi adalah "arbor" konsepnya yang abstrak. Dan, terdapat relasi langsung antara makna dan sumber pengambilan makna sebagai jangkarnya. Sebaliknya, tidak ada hubungan langsung dan alamiah antara penanda (signifier) dan petanda (signified) pada kasus arbor seperti yang kita saksikan dalam dunia nyata. Hubungan ini disebut relasi arbitrer. Validitas hubungan antara signifier-signified ini disebut mufakat (konvensi) “... a body of necessary convention adopted by society to enable members of society to use their language faculty" (Saussure, 1986).

Ahli semiotik lain (Van Zoest, 1993) menyampaikan lima ciri sebuah tanda antara lain: tanda harus dapat diamati, harus bisa ditangkap dengan indra, merujuk pada sesuatu yang lain jika intangible, bersifat representatif dan memiliki sifat interpretatif, merupakan dasar dari hal yang ditandakan. Tokoh semiotik Rusia, J.U.M. Lotman menambahkan bahwa "culture is constructed as hierarchy of semantic systems" (Lotman, 1971). Menjadi logis oleh karena sistem tanda meliputi unsur-unsur: sosial budaya dalam konteks sosial dan situasional, manusia sebagai subjek yang berkreasi, lambang sebagai dunia simbolik yang berproses melahirkan kebudayaan, dunia pragmatik dan wilayah makna.

Secara ringkas pendekatan semiotika dalam penelitian adalah metode untuk menganalisis dan memberikan makna-makna terhadap konsep dan proposisi-proposisi yang "terbentang” pada semua format penelitian deduktif kuantitatif maupun penelitian induktif kualitatif. Bahkan, semua lambang sebagai dokumen pendukungnya menjadi sebuah paket teks terurai yang dirunut secara berulang. Jadi, semiotika penelitian sesungguhnya adalah bidang studi tentang tanda dan cara tanda-tanda itu bekerja untuk melihat teks hasil penelitian sebagai penanda, dan makna yang dikembangkan darinya adalah petanda. Sebaliknya, dalam memahami studi tentang makna sendiri, sedikitnya terdapat tiga unsur utama yakni, (1) tanda, (2) acuan tanda (3) pengguna tanda.

Tanda merupakan sesuatu yang bersifat fisik, dapat dipersepsi indra manusia. Penelitian sendiri termasuk dalam kategori ini. Keseluruhannya sebagai tanda, juga mengacu pada sesuatu di luar tanda itu sendiri, yakni interpretasi dan hasil analisisnya, dan bergantung pada pengenalan penggunanya sehingga menjadi tanda. Menurut Saussure tanda adalah kesatuan yang tak dapat dipisahkan dari dua bidang seperti selembar kertas, yakni bidang penanda menjelaskan bentuk atau ekspresi; dan bidang petanda, menjelaskan konsep atau makna (Piliang, 2010). Selanjutnya Saussure menjelaskan bahwa konvensi sosial sangat penting untuk mengatur relasi antara wujud konkrit sebuah tanda dengan konsep abstrak atau makna. Dengan penegasan Saussure tersebut, peneliti menjadi yakin bahwa objek kajian apapun termasuk hasil penelitian dapat dikategorikan dalam sistem analisis ini, dan bahkan dapat diadopsi ke dalam pengertian dan prinsip dasar filsafat ilmu yakni: ontologiepistemologi dan aksiologi sebagai sebuah sistem menyeluruh. Pertanyaannya adalah apakah bentangan epistemologisnya mengalami dinamika penalaran dalam mendekonstruksi masalah penelitian yang dilakukan. Fakta menunjukkan bahwa masalah yang ada merupakan hasil rekonstruksi yang terus didaur ulang. Pertanyaan selanjutnya untuk dipikirkan bersama adalah apakah penelitian induktif aposteriori yang mengambil unit analisisnya pada hasil penelitian dosen-dosen sebuah fakultas mencakup semua dosen seluruh kampus di Indonesia.

Dalam konteks pertanyaan tersebut, peneliti mencoba meminjam bangunan pemikiran Charles S. Peirce yang sesuai dengan konteks penelitian ini berupa index dan simbol. Index adalah tanda yang mempunyai hubungan sebab-akibat dengan objek rujukannya; dan simbol adalah tanda yang mempunyai hubungan arbitrer dengan objeknya, yakni hubungan yang sewenang-wenang atau hubungan artifisial atau hubungan yang dibuat-buat. Dengan mengadopsi pengertian ini, peneliti ingin mengatakan bahwa hasil penelitian para dosen dapat berakibat pada nilai aksiologisnya yakni apakah akan bermanfaat pada pengembangan epistemologisnya dalam pengembangan ilmu pengetahuan dan teknologi. Jika tak mendapatkan jawaban memadai maka hasil penelitian hanya akan menjadi simbol dalam pengertian Peirce, bahwa hasil penelitian para dosen adalah tanda yang hanya mempunyai hubungan arbitrer dengan objeknya. Makna yang diberikan terhadap objek untuk penelitian deduktif, 
atau subjek penelitian untuk penelitian induktif tidak melahirkan sebuah makna yang signifikan, melainkan melahirkan sebuah antinomi baru.

Terkait paham strukturalisme dalam konteks penelitian ini, kita mengenal dua tokoh besar lain yang lama bergumul dengan semiotika adalah Roland Barthes dan Ernst Cassirer, yang mempelajari tanda sebagai suatu tingkatan yang memiliki makna dan memiliki karakter dalam aktivitas manusia yang mewujud dalam beragam bidang budaya manusia, seperti bahasa, seni, mitos, ritual keagamaan, sejarah, bahkan ilmu pengetahuan dan teknologi. Studi Barthes lebih fokus pada tanda-tanda yang dialami dalam konteks budaya masing-masing kelompok manusia. Sebagai contoh Barthes membedakan antara dua tingkatan signifikasi yakni denotatif yang bermakna literal sebagai level pertama, dan konotatif bermakna kontekstual kultural yang diasosiasikan bermakna mitos atau memasuki 'metabahasa' (Barthes, 1990). Jadi makna konotatif 'petanda' dalam konteks Barthes adalah makna yang disesuaikan dengan konteks budaya atau lingkungan budaya serta tradisi, yang pada masa silam direproduksi ke dalam acara-acara ritual. Acara ritual masa silam direproduksi sebagai 'tanda' (sign) dan dianggap sebagai sistem ritualitas. Misalnya, pakaian-pakaian tertentu hanya diperuntukkan bagi para rahib dan memiliki makna ritual dan bahkan bermakna religius seperti pakaian pendeta, pakaian raja, atau orang-orang suci (Eliade, 1989). Tanda-tanda bahasa bagi para pendoa juga dikategorikan dalam kelompok tanda sebagai fundasi dalam melaksanakan ibadah. Dalam beberapa acara keagamaan 'tanda-tanda' dianggap suci atau sakral dan direproduksi sebagai kekuatan yang bernilai religius, oleh karena kepemilikan tanda memerlukan kekuatan asali (Levy-Strauss, Claude; 1964).

Sering kali ‘tanda' mempunyai nilai ganda yakni nilai informatif atau referensial dan sugestifemotif, mirip dengan peran 'denotatif-konotatif' (Eco, 1982). Tanda yang bersifat informatif berfungsi menghantar pengetahuan akan dunia nyata. Semua hasil penelitian termasuk kategori ini. Sedangkan tanda-tanda yang bernuansa seni umumnya bersifat konotatif-kualitatif, yang memiliki sifat ambivalen atau ambigu, intrinsik dan dianggap sebagai warisan kekayaan dari kandungan pesan puisi (Jakobson, 1963) meskipun tidak kehilangan fungsi referensialnya. Dengan kata lain, ada bersama atau koeksistensi antara kedua sifat itu terdapat pada pakaian seperti desain pakaian batik. Sesuatu yang sifatnya non-figuratif mungkin tidak memiliki referensi dalam dunia nyata, akan tetapi memberi makna sebagai alat untuk 'representasi mental,' yang tidak membutuhkan eksistensi objek nyata, (Reboul and Moeschler, 1998). Lihatlah seorang artis selalu berupaya untuk mengubah sifat empiris dari fenomena dan tidak menawarkan yang dialami tetapi mewakili ‘citra’ (Hoffmann, 1966).

Bersandar pada teori-teori yang kokoh pada pembahasan ini, penulis ingin menyampaikan sebuah ringkasan pemikiran sebagai 'the state of the art'studi semiotik penelitian yang dianggap sebagai tanda (sign) dan menjadi simbol semiotik komunikasi. Pada observasi pendahuluan, penelitian difokuskan pada objek dokumen dan hasil penelitian beberapa dosen sebagai unit analisisnya.

Distingsi-distingsi untuk menyaring dikotomi fenomena adalah pembuktian inti peneliti untuk menemukan tanda-tanda yang terkonstruksi, dan pada ujung pergulatan, peneliti berupaya memproduksinya menjadi sebuah makna tertentu.Selanjutnya bagaimana bentuk pertanyaan penghayatan terhadap deskripsi penelitian para dosen. Komunikasi sebagai transmisi pesan melihat fenomena untuk diproduksi demi pertukaran sebuah makna yakni bagaimana informasi emotif atau pesan tertentu berinteraksi dengan orang disekitar fenomena untuk menghasilkan suatu makna baru dari hasil penelitian para ilmuan kampus.

Charles Sanders Peirce menegaskan bahwa kita hanya bisa berpikir dengan sarana 'tanda'. Tanpa tanda manusia tidak dapat berkomunikasi, oleh karena tanda-tanda berkaitan erat dengan objekobjek yang menyerupai, keberadaannya memiliki hubungan sebab-akibat dengan tanda-tanda karena ikatan konvensional dengan tanda-tanda tersebut. Peirce menggunakan icon untuk kesamaannya, index untuk hubungan sebab-akibat dan simbol untuk asosiasi konvensional. Dengan demikian analisis semiotik penelitian memberi kemungkinan untuk melihat sebuah hasil penelitian sebagai 'tanda' tidak 
hanya dari perspektif referensial dan informatif, melainkan lebih jauh mampu mengungkap aspekaspek lain yang lebih kontekstual dan bersifat kultural dan tidak hanya mengulang sebuah kebiasaan yang didaur ulang. Dengan kata lain, mengungkap fenomena penelitian sebagai tanda dari sisi denotasi adalah suatu keharusan oleh karena peneliti telah menjangkau subjek penelitian. Namun, menjangkau makna konotatif dibalik penelitian sebagai tanda yang teramati, jauh lebih penting untuk mengkonstitusi penanda (signifier) yakni hasil penelitian para dosen dan petanda (signified) yakni makna yang diberikan peneliti sebagai proposisi-proposisi yang dipahami dan diinternalisasi lebih lanjut.

\section{SIMPULAN}

Secara denotatif objek atau fenomena penelitian para dosen diserap dan ditangkap dengan indra sebagai bentangan hasil penelitian yang berwujud penanda (signifier). Namun, kedalaman objek atau fenomena hasil penelitian tersimpan makna sebagai noumena yang tersembunyi yang perlu diinterpretasi berdasarkan jangkar-nya yakni realitas yang nampak pada penanda-nya. Dari perspektif Barthes makna konotatif tingkat kedua terasa mendekat. Namun, ketika meminjam dan menghadirkan perspektif Peirce, ke-dua-an atau binary opposition Barthes menjadi tak terlihat.

Index mencari hubungan sebab-akibat. Jika hasil penelitian adalah fenomena bermakna index sesuai konsep Peirce maka akibatnya akan melahirkan nilai aksiologis yang akan berdaur ulang dalam pengembangan epistemologisnya. Sebaliknya, simbol mencari hubungan asosiatif konvensional, tidak akan menemukan makna ilmiah oleh karena hubungan aktivitas ilmiah dengan makna interpretatifnya bersifat arbitrer. Harapan penulis adalah mencari komodifikasi fenomena dari hasil penelitian para dosen yang bermuatan nilai epistemologis dalam pengembangan nilai-nilai ilmiah yang membudaya di kampus-kampus. Kenyataan sementara di lapangan menunjukkan ketidaksamaan harapan oleh karena keterbatasan yang ada. Komodifikasi dalam konteks tulisan ini adalah suatu upaya untuk mengubah apapun menjadi komoditas demi sebuah makna baru menurut perspektif penulis dan peneliti.

Pada semiotika penelitian para dosen, Peneliti berharap bahwa makna tidak akan berhenti pada level kedua Barthes, namun akan muncul dinamika baru dan memberi warna baru pula sebagai penanda-petanda yang memiliki dasar epistemologis yang kuat dalam rangka pembentukan nilai-nilai ilmiah para dosen komunikasi untuk diwariskan bagi para mahasiswa ilmu komunikasi di kampuskampus di Indonesia.

\section{DAFTAR PUSTAKA}

Barthes, R. (1990). The Fashion System. Los Angeles: University of California.

De Saussure, F. (1990). Course in General Linguistics. London: Duckworth.

Eco, U.(1982). Opera Aperta. Milano: Bompiani.

Piliang, Y. A. (2010). Semiotika dan Hipersemiotika. Bandung: MATAHARI.

Sobur, A. (2006). Analisis Teks Media. Bandung: Remaja Rosdakarya.

Ulani Yunus \& Dominiq Tulasi (2012). Batik Semiotics as a Media of Communication in Java. Cultura: International Journal of Philosophy of Culture and Axiology.

Van Zoest, Aart (1993). Semiotika: Tentang Tanda, Cara Kerjanya dan Apa yang Kita Lakukan Dengannya. Jakarta: Yayasan Sumber Agung. 